\title{
Impacts of anthropogenic and environmental factors on the occurrence of shallow landslides in an alpine catchment (Urseren Valley, Switzerland)
}

\author{
K. Meusburger and C. Alewell \\ Institute of Environmental Geosciences, University of Basel, Bernoullistrasse 30, 4056 Basel, Switzerland \\ Received: 4 January 2008 - Revised: 12 March 2008 - Accepted: 9 April 2008 - Published: 19 May 2008
}

\begin{abstract}
Changes in climate and land use pose a risk to stability of alpine soils, but the direction and magnitude of the impact is still discussed controversially with respect to the various alpine regions. In this study, we explicitly consider the influence of dynamic human-induced changes on the occurrence of landslides in addition to natural factors. Our hypothesis was that if changes in land use and climate have a significant influence on the occurrence of landslides we would see a trend in the incidence of landslides over time. We chose the Urseren Valley in the Central Swiss Alps as investigation site because the valley is dramatically affected by landslides and the land use history is well documented. Maps of several environmental factors were used to analyse the spatial landslide pattern. In order to explain the causation of the temporal variation, time-series (45 years) of precipitation characteristics, cattle stocking and pasture maps were compared to a series of seven landslide investigation maps between 1959 and 2004. We found that the area affected by landslides increased by $92 \%$ from 1959 to 2004. Even though catchment characteristics like geology and slope largely explain the spatial variation in landslide susceptibility (68\%), this cannot explain the temporal trend in landslide activity. The increase in stocking numbers and the increased intensity of torrential rain events had most likely an influence on landslide incidence. In addition, our data and interviews with farmers pointed to the importance of management practice.
\end{abstract}

\section{Introduction}

Topographic and climatic extreme conditions make the mountain environment vulnerable to changes of climate and land use (Cernusca et al., 1998). Due to changes of climate

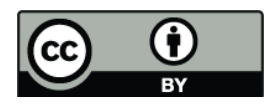

Correspondence to: K. Meusburger (katrin.meusburger@unibas.ch) and land use the potential risks of torrents, snow gliding, avalanches, soil erosion and landslides may increase. Soil and slope stability are a crucial precondition to preserve the functions of the mountain environment, for example water supply, nutrient production, biodiversity, aesthetics, and cultural heritage. Landslides endanger slope stability and the resource soil in mountains areas all over the world (Glade, 2003; Ohlmacher and Davis, 2003; Shrestha et al., 2004; Ayalew et al., 2005), as one extreme event can constitute a great proportion of total soil loss while recovery of soil characteristics is very slow (Sparling et al., 2003).

The effect of environmental catchment characteristics on the probability of landslides is well understood and commonly used to predict landslide risk. Most of the investigated triggering factors are quasi-static in time i.e. do not change their characteristics in the considered time-span (such as geology, topography, etc.). Several studies showed the decisive impact of geology and slope as proxies for the physical parameters that describe soil strength properties and gravitational forces (Carrara et al., 1991; Rickli et al., 2001; Dai and Lee, 2002; Zhou et al., 2002; Ohlmacher and Davis, 2003; Santacana et al., 2003; Van Westen and Lulie Getahun, 2003; Suezen and Doyuran, 2004; Ayalew and Yamagishi, 2005; Clerici et al., 2006; Komac, 2006). However, the effect of triggering factors which are variable with time due to anthropogenic influence such as land use and climate (here defined as "dynamic factors") are only rarely considered.

Even tough there is no doubt that land use has a significant effect on the probability of landslides (Schauer, 1975; Bunza, 1984; Glade, 2003; Tasser et al., 2003; Petley et al., 2007), its influence is still discussed controversially in literature with respect to the various mountainous regions (Douglas et al., 1996; Andre, 1998; Tasser and Tappeiner, 2002; Krohmer and Deil, 2003). Overall it is not clear yet, whether we can expect a reduced erosion risk due to reforestation of mountain slopes or an increase due to abandonment and intensification of remote sites in alpine regions.

Published by Copernicus Publications on behalf of the European Geosciences Union. 


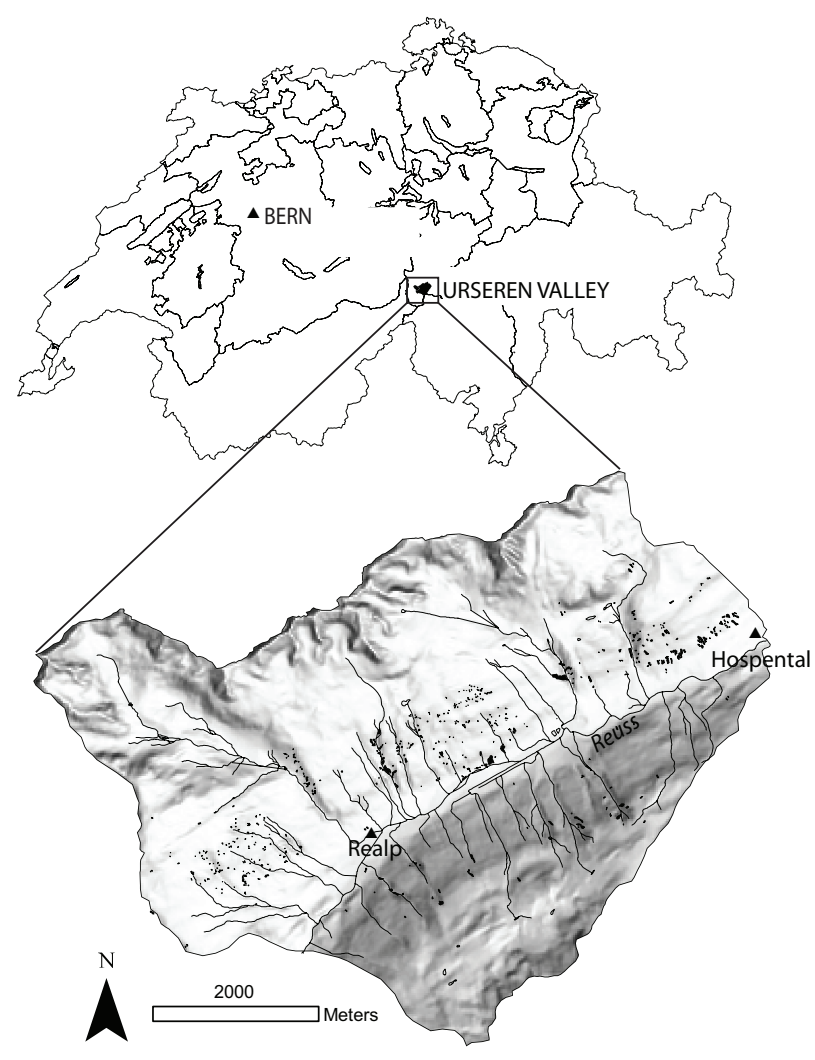

Fig. 1. Map of Switzerland and the study area (Projection: CH1903 LV03).

The assessment of the impact of the above-discussed human-induced changes is a crucial requirement for land managers and policy makers in order to initiate prevention measures. Unfortunately, the impact of the human-induced changes on landslide is difficult to quantify, due to the high natural variability and geomorphic feedback mechanisms. Only few studies exist that could relate actual impact of anthropogenic changes with trends in landslide activity. The main method to study trends in landslide incidence is based on the application of physically based slope stability models, which were applied to simulate former climate and land use conditions (Collison et al., 2000; Vanacker et al., 2003; Schmidt and Dikau, 2004; Claessens et al., 2006). Another possible method is to analyse landslide databases in relation to other human-induced trends in landscape and climate change (Petley et al., 2007). We will pursuit the latter approach in our study due to the lack of most of the physical parameters related to the modelling of land use change.

Our aim is to evaluate, if the above described land useand climate changes cause a trend in landslide occurrence and to determine possible causes for the temporal variation. Our hypothesis is that if anthropogenic changes have had an impact on landslide triggering it will be expressed by a trend in landslide occurence, since changes of land use and climate change in the Alps have been evident for decades. For example, the processes of abandonment, extensification and reforestation occur since the early 1960s (Ritzmann-Blickenstorfer, 1996; BFS, 2001; Descroix and Gautier, 2002; Piégay et al., 2004). The process of global warming is most evident in the Alps by the melting glaciers since 1850 (Frei et al., 2007).

The Urseren Valley (Central Swiss Alps) was chosen as investigation site for two reasons; (i) the valley is dramatically affected by landslides and (ii) land use history is well documented. The valley slopes are also affected by sheet erosion, which is addressed and evaluated in other ongoing studies. (Alewell et al., 2008; Brodbeck and Alewell, 2008 ${ }^{1}$ ). Here, we explicitly focus on landslides in consequence of soil instability.

\section{Study area}

The sub-alpine study area $\left(30 \mathrm{~km}^{2}\right)$ is located in the Urseren Valley (Switzerland) and is discharged by the river Reuss (Fig. 1). The wide glaciated valley is characterised by a Ushaped profile and a rugged terrain. Elevation ranges from 1400 to $3200 \mathrm{~m}$ a.s.l. The predominant slope angle is approximately $27.2^{\circ}$.

The valley corresponds to a geological fault line that separates the gneiss massif of the Gotthard system to the south from the granite massif and the pre-existing basement (named by "Altkristallin" by Labhart, 1999), of the Aare system in the north. Intermediate vertically dipping layers along the fault line consist of Permocarbonic and Mesozoic sediments (Labhart, 1999). During the Permocarbon sandyclay sediments deposited and during the Mesozoic, different materials from the geological periods Trias (sandstone, rauhwacke and dolomite), Lias (dark clay-marl and marl) and Dogger (clays, marl and limestone) deposited. Throughout the mountain building the material was metamorphosed to schist (Kägi, 1973; Angehrn, 1996). Due to erosion of these soft layers a depression developed (Kägi, 1973). The direction of the strike of these sediments from SW to NE corresponds to the valley axis. Weathering of the calcareous material produced marls that are prone to landslides. Riverbeds are characterised by glaciofluvial deposits. On the valley slopes, Quaternary moraines and talus fans are common and consist mainly of siliceous loamy gravel material. The reader is referred to Wyss (1986) for a detailed description of the tectonic and lithostratigrapical evolution of the region.

Dominant soil types in the catchment, classified according to WRB (2006), are Podsols, Podzocambisols and Cambisols. Above $2000 \mathrm{~m}$ a.s.l. and on steep valley slopes, Leptosols are common (with rendzic Leptosols on the calcareous substrates). At the valley bottom and lower slopes,

\footnotetext{
${ }^{1}$ Brodbeck, M. and Alewell, C.: Stable carbon isotopes as an indicator for soil degradation in an alpine environment (Urseren Valley, Switzerland), Eur. J. Soil Sci., submitted, 2008.
} 
predominantly clayey gleyic Cambisols, Histosols, Fluvisols and Gleysols developed.

The valley is characterised by a high mountain climate with a mean air temperature of $3.1^{\circ} \mathrm{C}(1901-1961)$. The temperatures of the last years (1961-2006) show a deviation of $1.5^{\circ} \mathrm{C}$ higher temperatures compared to the long term mean (1901-1961) (Angehrn, 1996). Mean annual rainfall at the climate station in Andermatt $\left(8^{\circ} 35^{\prime} / 46^{\circ} 38^{\prime} ; 1442 \mathrm{~m}\right.$ a.s.1.) of MeteoSwiss located at the outlet of the valley is about $1400 \mathrm{~mm}$. The valley is snow covered for 5 to 6 month (from November to April) with the maximum snow height in March (Angehrn, 1996). The rainfall maximum occurs in October, the minimum in February. Runoff is usually dominated by snowmelt in May and June. Nevertheless, summer and early autumn floods represent an important contribution to the flow regime. The peak runoff period is in June (BAFU, http://www.hydrodaten.admin.ch/d//2087.htm; Access date: 06.08.2007).

Vegetation shows strong anthropogenic influences due to pasturing for centuries (Kägi, 1973). Particularly on the less productive north-facing slope an invasion of shrubs mainly by Alnus viridis, Calluna vulgaris, Salix appendiculata, Sorbus aucuparia, and Rhododendron ferrugineum is evident (Kägi, 1973; Küttel, 1990b). Dwarf-shrub communities of Rhododendron ferrugineum and Juniperus sibirica (Kägi, 1973; Küttel, 1990b) and diverse herbs and grass species dominate on the fertile south-facing slope. The four main land cover types are: $63 \%$ alpine grasslands including dwarfshrubs (mainly consisting of Calluna vulgaris, Rhododendron ferrugineum, Juniperus sibirica), 16\% debris (grassland with more than $70 \%$ boulders), $11 \%$ bare rock at higher elevations, and $8 \%$ shrubs (mainly consisting of Alnus viridis and Sorbus aucuparia) approximately one third of it invaded since 1959 and will be termed "new shrub" in the following. Urban and forest areas each represent less then $1 \%$ of total area. Today's forests were cultivated for avalanche protection above the villages. Deforestation of the valley started in 1100 with the first settlement due to agricultural activities and scarcity of timber. Associated with the deforestation are frequently occurring avalanches (Küttel, 1990a).

The cultural landscape of the valley is dominated by pasturing. Private owners and Korporation Urseren own the land. The alp areas of the Korporation Urseren are traditionally used as summer pastures. The private land serves as hay meadows to feed the cattle during the winter month. Meadows are treated with organic fertilizer and mown once or twice a year. The relevance of farming gradually decreased during the last decades. In addition, the number of full time farmers and farms decreased. Kägi (1973) already observed that, "the traditional principles of land use are dissolving".

\section{Materials and methods}

A time-series of landslide inventory maps was generated based on air photographs of seven different years starting in 1959. The occurence of landslides over time was then tested for a significant trend with the Neumann trend test. The landslide inventory maps were then superimposed with environmental factor maps and analysed with multiple logistic regression. In order to illustrate the relation between landslides and causative factors, bivariate statistic is applied for the factors geology, slope, avalanche density, and land-cover. Finally, the evolution of landslide occurrence over time was compared to time-series of dynamic factors, such as climate (precipitation and avalanches) and land use characteristics (stocking numbers and management practice). The database construction and spatial overlay of the data layers was accomplished with the geographic information system (GIS) software ArcGIS (ESRI) version 9.1.

\subsection{Mapping of landslides from air photographs}

Landslides in the investigation area $\left(30 \mathrm{~km}^{2}\right)$ were mapped by visually vectorising the affected area from air photographs (Swisstopo, 2006). The photographs had a scale of at least 1:12000 and were available for seven different years: 1959, 1975, 1980, 1986, 1993, 2000, and 2004.

The photographs from 1959 to 1993 are black and white images with no geometrical corrections. In order to allow for local comparison of individual landslides between different years the photographs were georeferenced and orthorectified. The geometrical corrections were done with the help of ground control points, the DEM (25 m grid) and the camera calibration protocols (Swisstopo, 2006). For the years 2000 and 2004 the orthorectified RGB "Swissimages" (air photographs with geometrical corrections) with a pixel resolution of $0.5 \mathrm{~m}$ could be directly used without pre-correction. Field verification in 2005 was performed to check the inventory map of 2004. During the field excursions, the maximal width and length of ten landslides was measured and compared to corresponding distances digitised by the photo interpretation mapping method. The resulting deviation between the two methods was approximately $10 \%$ which we took as the assumed error of the areal mapping method.

\subsection{Mapping of environmental factors}

\subsubsection{Quasi-static factors}

The topographical parameter slope was calculated from the DEM with a three-pixel kernel. A geological map at a scale of 1:200000 (Labhart, 1999) formed the basis for a revised geological map, that was supplemented by field mapping and air photograph interpretation. This revised geological map, constructed as digital polygons, was then converted to raster format. ArcGIS density functions were used to obtain a raster map of avalanche. The avalanches that occurred 
since 1695, recorded by the Swiss Federal Institute for Snow and Avalanche Research Davos, were averaged for each pixel with $500 \mathrm{~m}$ moving window to generate the avalanche density map.

\subsubsection{Time-series of land use, land-cover and climate data}

The present and past land use was determined by a series of pasture maps of the years 1955, 1975, 1990, and 2006 (Russi, 2006) that were digitised and georeferenced. We conducted semi-structured interviews with two farmers concerning changes of land use within the last decades to supplement the pasture map information (FAO, http://www.fao.org/ docrep/x5307e/x5307e08.htm; Access date: 06.08.2007). One of them was acting as a farmer elected to oversee common lands for 16 years. Quantitative information on stocking on the pastures was obtained from the archive of the Korporation Urseren (Russi, 2006). The stocking numbers together with the pasture maps were used to calculate stocking densities (area per animal) for four different years. In the following we will address the stocking densities (animal/area) as land use intensity. Information on the land-cover was available from the Vector25 dataset (Swisstopo, 2006). The dataset was last actualised in 1993, thus, it was updated with the air photograph of 2004 to display the present-day situation. The land-cover was additionally mapped for the year 1959 (based on air photograph interpretation) to assess potential changes of land-cover with a spatial overlay.

Climate data with daily rainfall was supplied by MeteoSwiss for the Andermatt station from 1971 to 2006. The avalanches that occurred in the valley were summarized for each year to generate a time-series of avalanche frequency.

\subsection{Analysis of environmental factors}

\subsubsection{Quasi-static factors}

In order to identify the most relevant environmental factors a multi-collinearity analysis followed by multiple-logistic regression with forward selection method was used.

To illustrate the causative relationship of selected quasistatic factors and landslide occurrence, we used bivariate analysis to produce landslide density histograms (landslide occurrences within each factor map and within each factor map's classes). For bivariate analyses, a categorisation of the continuous factor maps is necessary. The landslide densities are calculated according to equation:

$D_{i}=\frac{S X_{i}}{X_{i}} * 100 * \sum_{k=1}^{n} \frac{X_{i=k}}{S X_{i=k}}$

in which $D_{i}=$ landslide density for a variable class, $S X_{i}=$ number of pixels with landslides within a variable class, $X_{i}=$ number of pixels within variable class and $\mathrm{n}=$ number of variable classes. The division of $S X$ by $X$ eliminates the effect of different areal extends of the classes. To ease the comparability between landslide densities of different classes a normalisation with the sum of landslide densities for all classes was done. ArcGIS 9.1 provides the ready applicable tool "zonal statistic" to simplify the calculation of the ratio between the areas occupied by landslide pixels within each class of a certain factor map. This procedure is repeated for all factor maps.

\subsubsection{Time-series of climate data and land use}

The mean precipitation data and torrential rainfall events were tested for a trend with the Mann-Kendall's Tau test (Helsel et al., 2006). To assess the influence of dynamic factors, the development of the number of landslides was compared and correlated (Spearman's rank correlation) to the maximum precipitation event (yearly maximum 1 dayevents, -3 day-events and -5 day-events; yearly mean precipitation), that occurred in the corresponding period, stocking properties (cumulative stocking and increase of stocking within the years, absolute stocking numbers), and avalanche frequency. In order to avoid pseudo-replication only the number of new landslides (not the increased area of existing slides) between each mapped year was used for the correlation. Thus, increase in landslides means that newly affected areas are spatially separated from older ones.

\section{Results and discussion}

\subsection{Relation of landslides to natural quasi-static factors}

In 2004 a total of 383 shallow landslides $\left(>25 \mathrm{~m}^{2}\right)$ with a total area of $9.42 \mathrm{ha}$, an average size of $250 \mathrm{~m}^{2}$, and an average slope of the landslide area of $33.9^{\circ}$ were mapped with air photograph interpretation. The areal extent of the largest detected landslide is about $7000 \mathrm{~m}^{2}$.

A collinearity diagnosis of the quasi-static factors identified several cross-correlations. As was shown by Meusburger and Alewell $(2008)^{2}$. Geology, slope and avalanche density were distinguished as independent factors with variance inflation factors $(\mathrm{VIF})<2$. The subsequent multiple-logisticregression identified the geology as the most dominant factor followed by slope (for both $\mathrm{P}<0.0001$ ). Avalanche density did also significantly $(P=0.002)$ improve the explained spatial variance.

Landslide density histograms illustrate the spatial dependence between the mapped landslide pattern and environmental factors (Fig. 2). Regarding geology (Fig. 2a), landslide density was highest in the Mesozoic formation and the Altkristallin (47.1\% and $36.4 \%$, respectively). Calcareous rock of the Mesozoic formation, weathered to clay, forming soils with stagnic properties, which are particularly prone

\footnotetext{
${ }^{2}$ Meusburger, K. and Alewell, C.: The influence of land use change on the validity of landslide susceptibility maps, Earth Surf. Proc. Land, under revision, 2008.
} 

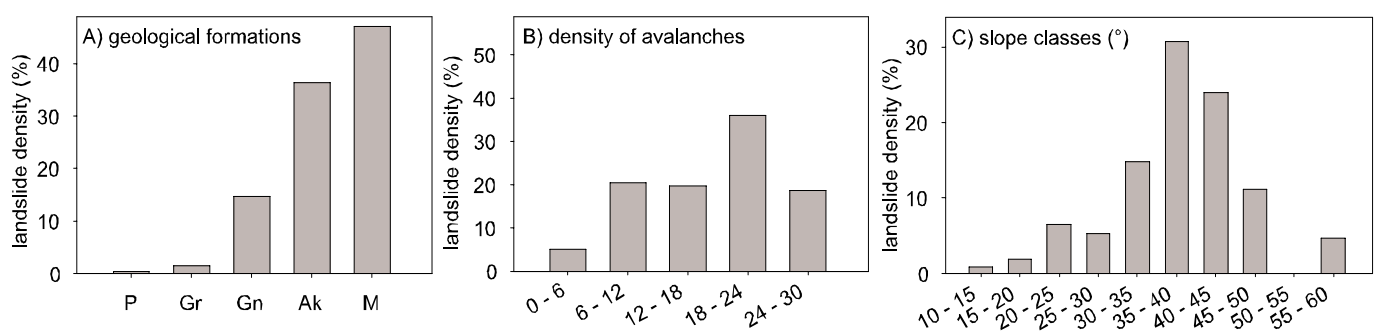

Fig. 2. The landslide density histogram as dependent on (A) geology (for the permocarbonic- (P) and mesozoic-sediments (M), Granite of the Aare massif (Gr), Gneiss of the Gotthard massif (Gn) and "Altkristallin" (Ak) by Labhart, 1999), (B) avalanche density, and (C) slope.

to landslides due to their layered and water ponding character. The Altkristallin, adjacent to the Tavetscher fault line, is a highly deformed and instable clay schist. Both bedrock units of this class occur only along the lower south exposed slope. Even though the Permocarbon is also a sediment layer it shows lowest susceptibly to landslides due to is location at the flat valley floor. Our results seem to confirm the widely recognised view that geology greatly influences the occurrence of landslides as it determines the strength and permeability of rock as well as the resultant cohesion of the soil layer (Carrara et al., 1991; Guzzetti et al., 1999; Dai and Lee, 2002).

Gravitational forces are decisive beside material properties. We observe that the probability of landslides increases with slope angle and peaks at gradients ranging between $35^{\circ}$ to $40^{\circ}$ (Fig. 2b). This slope angle corresponds well with literature values for other alpine grasslands (Dommermuth, 1995; Rickli et al., 2001; Tasser et al., 2003). For steeper slopes the landslide susceptibility decreases again most likely because soil cover becomes thinner through continuous sheet erosion. A thinner soil cover is less susceptible to landslides because less gravitational forces occur. In general, landslide susceptibility increases with increasing slope angle and soil depth (Carson, 1971).

Avalanche density (since 1695) is a further parameter which might influence landslide distribution. Landslide density increases with increasing avalanche density in the Urseren Valley (Fig. 2c). The exception is the class with the highest avalanche density (24-30) that is located in elevated and steep terrain where soil cover is scarce and rock and debris are dominating land-covers. Interference with geology may be the reason for the increased value of the class with 6 to 12 avalanches. A spatial relationship is evident even though the causal relation is questionable because stability of snow cover depends on similar topographical conditions as the stability of soil cover. The latter will be discussed in more detail in connection with the time-series data in the following chapter.

It is very likely, that the pattern of the mapped landslides is not only showing a statistical correlation but also a causative relationship to the quasi-static, environmental factors geology and slope. Other risk assessment studies also identified
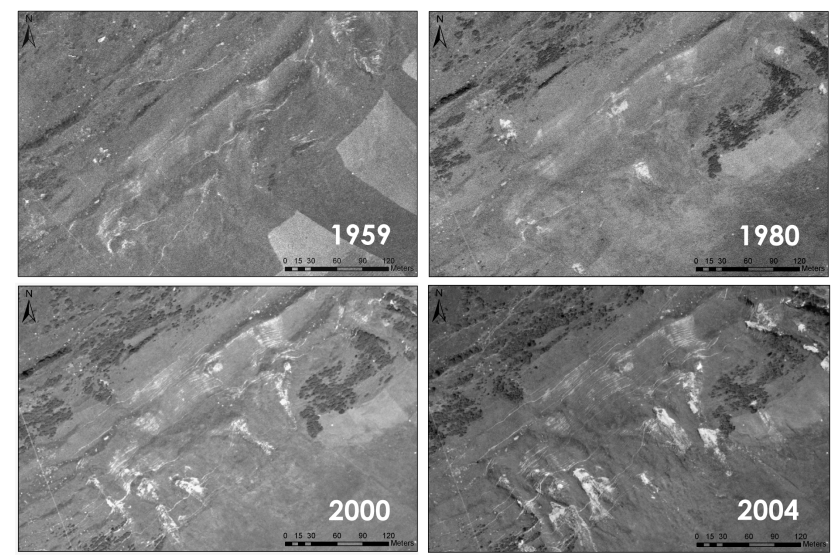

Fig. 3. Sub-images of air photographs showing the stages of landslide hazard for the years 1959, 1980, 2000, and 2004.

geology and slope to be the most decisive quasi-static catchment characteristics (Ohlmacher and Davis, 2003; Suezen and Doyuran, 2004; Ayalew and Yamagishi, 2005). However, beside the static environmental catchment conditions, the relevance of dynamic anthropogenic changes on the temporal evolution of landslide incidence is crucial to know.

\subsection{Evolution of landslide incidence compared to human- induced changes}

The area affected by landslides increased dramatically since 1959. Figure 3 gives a visual impression of the destabilisation of a lower south-exposed slope over the years. The mapping of the stages of landslide incidence revealed that, once the slope is degraded by trails and landslides, it might take decades to recolonise the bare spots with vegetation.

The Neumann-test shows a significant increasing trend $(\mathrm{P}<0.01)$ for landslide numbers and landslide area. While the number of landslides continuously increased with time, the increase of eroded area happened in two phases: from 1959 to 1980 by $45 \%$ and from 2000 to 2004 by $32 \%$ (Fig. 4). From 1980 to 2000, new landslides occurred but the total affected area did not increase due to partial regeneration of older landslides. In total, the eroded area nearly doubled 


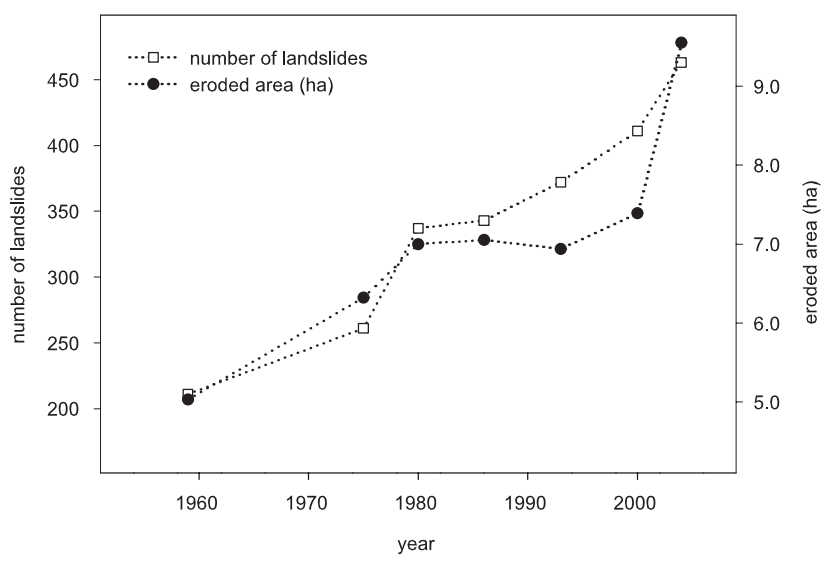

Fig. 4. Progression of the number of landslides and eroded area by landslides for the entire catchment since 1959 . The error of the mapped landslide area is approximately $10 \%$.

between 1959 and 2004 (increase of 92\%). The average depth of 10 measured landslides was $1.5 \mathrm{~m}$. Given the eroded area and assuming a bulk density of $1.2 \mathrm{t} \mathrm{m}^{-3}$, we estimated a mean sediment rate of $0.6 \mathrm{tha}^{-1} \mathrm{yr}^{-1}$ due to landslides only. According to sheet erosion rates for agricultural low lands, this value is classified as low soil loss. However, due to the higher vulnerability of alpine regions the areal damage is dramatic.

In order to explain the increasing trend, the evolution of landslide incidence is compared to other causative factors that changed over time and have a geophysical association to landslide triggering, as described below. Trends in landslide activity might also be caused by geomorphologic feedback mechanisms i.e. older landslides can undercut and steepen a slope and trigger new landslides. However, the induced feedback mechanisms are not exclusively positive. Claessens et al. (2007) showed that landslides also stabilise some parts of the slope due to the canalisation of the runoff in the eroded area. A quantification of the balance between stabilising and destabilising feedback effects could not be accomplished for the scale considered in our study. Thus, an effect of positive feedback mechanisms might be involved in the observed trend in landslide activity. Moreover, new landslides occurred mostly sideways to older ones or at sites, that were formerly free of landslides (note that triggering interactions show a upslope/downslope shifting pattern (Claessens et al., 2007). We thus assume that legacy effects are of minor importance. The use of hydropower and accompanying changes of slope humidity can be excluded as possible explanation for the landslide increase, because the hydropower station in Realp was already commissioned in 1913 (EWU, http://www.ew-ursern.ch/docs/wasserkraft.cfm; Access date: 06.08.2007).
4.2.1 Climate factors: avalanche frequency and precipitation

The analysis of time-series data showed that several dynamic factors change simultaneously in the Urseren Valley. This impedes the determination of a definite causation of the landslide trend. Moreover, the temporal resolution of the air photographs to analyse the landslides is too low and too irregular, to deduce significant correlations. Nonetheless, in the following correlation coefficients are presented to supplement the graphical illustrations.

Climate change affects soil stability directly via modification of precipitation characteristics and via temperature effects on soils (e.g. melting of permafrost). Indirect effects include the alteration of vegetation cover and snow processes. We evaluated the frequency of avalanches over time as one important proxy for changes in snow dynamics. Avalanches are regarded as potential landslide risk factors because of the additional friction forces that may trigger tension fissures. The time-series of avalanches show a slightly increasing trend of the linear regression. However, the latter is only due to the high number of avalanches in the winter of 1999 (Fig. 5 left). Apart from that extreme event no trend over time is distinguishable. A direct comparison between the timeseries of the number of avalanches and number of landslides for single years in the valley did not result in a clear relation$\operatorname{ship}\left(r_{s p}=-0.43, P=0.38\right)$. Although there is a connection between spatial pattern of avalanches and landslides (Fig. 2b, see discussion above), no temporal correlation was found, e.g. the winter of 1999 with 30 avalanches did not cause a noticeable rise of the eroded area in 2000. Avalanches might trigger landslide events in subsequent years due to a general destabilisation of slopes. However, the absence of tension fissures in the field and the time-series data lead to the conclusion that avalanches do not directly triggered landslides at our site but rather occur in the same places, because the stability of snow cover and stability of soils are controlled by similar environmental conditions. To conclude, we could not identify avalanches as a causative factor for the landslide trend.

Generally, landslides and precipitation are related by a threshold function (Guzzetti et al., 1999; Zhou et al., 2002) as soil strength properties are a function of soil water content. However, the Spearman correlation coefficients between precipitation characteristics (yearly maximum 1 day-events, 3 day-events and -5 day-events; yearly mean precipitation) and landslides were not significant. The Mann-Kendall's Tau test was not significant for mean precipitation data of the Andermatt station, too. However, for torrential events $>150 \mathrm{~mm}$ $3 \mathrm{~d}^{-1}$ a significant $(\mathrm{P}<0.05)$ increase of $1.32 \mathrm{~mm} 3 \mathrm{~d}^{-1}$ per year is evident (Fig. 5 right). Thus exceedance of the landslide triggering threshold became more likely.

Farmers confirmed that prolonged rainfall of $2-3$ days triggers landslides. The maximum event in the observed period occurred in November 2002 (270 mm in three days), which 

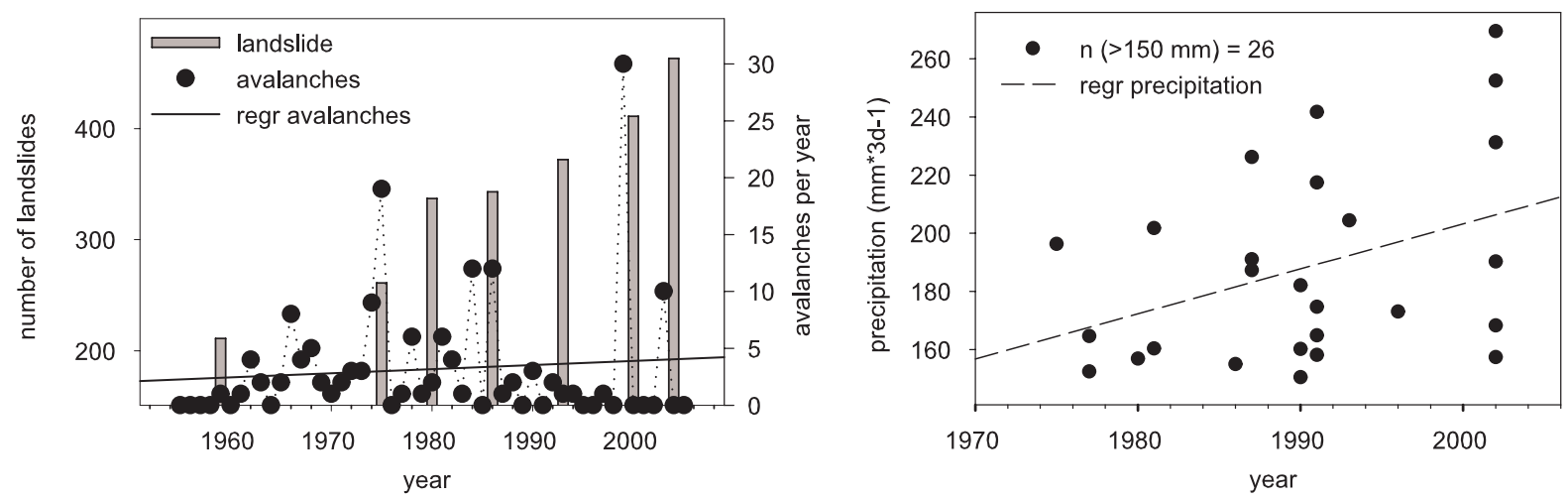

Fig. 5. Increase of the number of landslides in comparison to the climate factors: frequency of avalanches per year (left) and yearly maximum 3-days precipitation events (right).
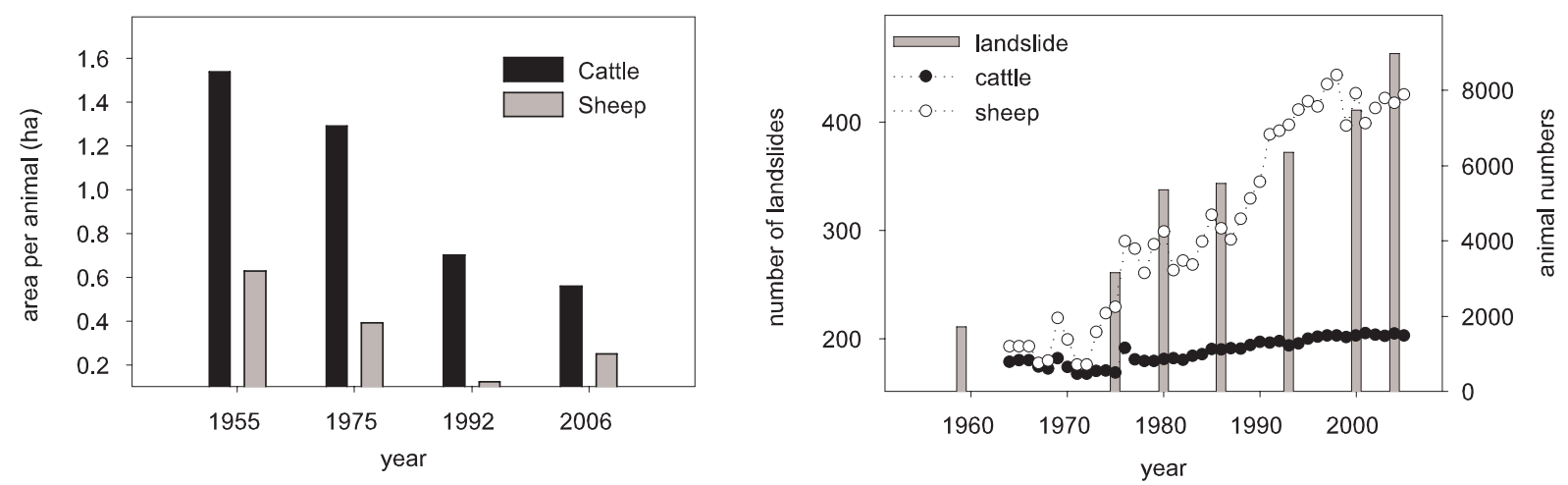

Fig. 6. Land use intensification (left) and a comparison between the increased landslide- and stocking numbers (right).

triggered at least 17 landslides (Berger, August 2005; Swissphoto; personal communication) and mainly contributed to the affected area we observe in 2004. Extreme events from August 1987 (226 mm in three days) and November 1991 (242 $\mathrm{mm}$ in three days) also triggered several landslides. However, no triggering event could be observed between 1993 and 2000.

The observed increased frequency and intensity of torrential rainfall events is in correspondence with the generally described climate change effects (IPCC, 2007). Moreover, precipitation is expected to increase more in the winter (Beniston, 2006) when vegetation is sparse. The most severe events were observed in November in the Urseren Valley. On lower altitudes, precipitation will less often fall as snow while for higher altitudes a thicker snow pack in spring is predicted that results in more intense snowmelt events (Beniston, 2006). Thus, landslide hazard can be expected to increase through the described effects (Frei et al., 2007). Our analysis of extreme 3-day precipitation events seem to confirm this statement.
4.3 Land use factors: Intensity, management practices and land-cover

\subsubsection{Land use intensity}

Besides the climatic factors the triggering of landslides is dependent on intensity and type of land use (Schauer, 1975; Bunza, 1984; Tasser et al., 2003). Land use was mainly intensified in the valley during the last decades, which is shown by the decreasing pasture area per animal (Fig. 6 left). Since 1955, the pasture space per cow steadily decreased for two reasons (i) an increase in cow numbers from 785 to 1482 and (ii) a reduction of cow pasture area. Pasture area per sheep also decreased until 1992 due to an increase of sheep from 1193 in 1955 to 7875 in 2006 . The sheep pastures were enlarged in 2006. Goats are of minor importance in the valley and decreased from approximately 550 goats in 1976 to 280 in 2005 .

Except between 2000 and 2004, a good correspondence between increase of stocking number and landslides could be observed (Fig. 6 right). However, correlations between the increase of stocking numbers (sheep $r_{s p}=0.10, P=0.87$, cattle $r_{s p}=0.35, P=0.56$ ) and new landslides of corresponding 

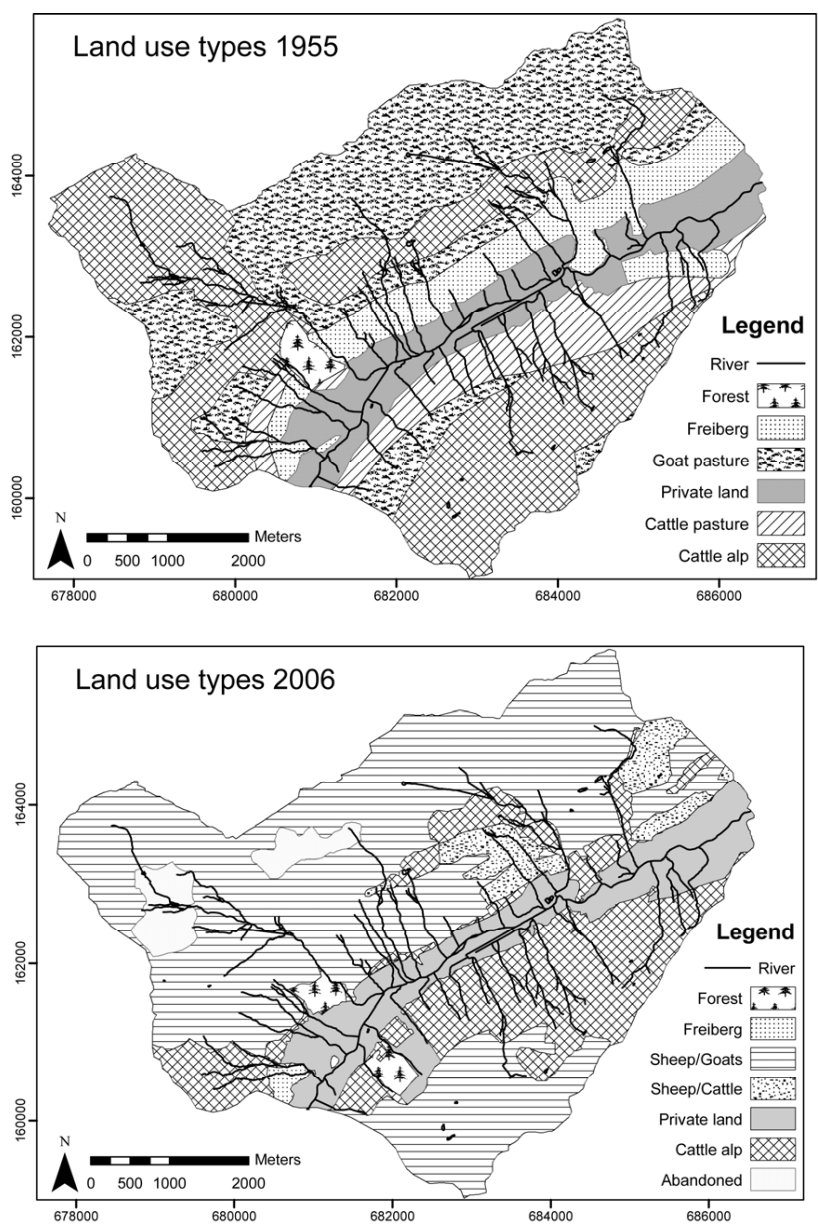

Fig. 7. Pasture maps for the year 1955 and 2006.

years was not significant. One reason is that the interaction with the triggering rainfall event and even the timing of the event needs to be considered. A multiple regression with stocking increase and yearly maximum 3 day-events could improve the explained variance $(R=0.4)$ of the landslide development but was still not significant. Both predictors showed similar significance in the multiple regression (stocking number of sheep and cattle $P=0.52$, yearly maximum 3 day-events $P=0.58$ ). A reason for the low significance of the predictors is the usually non-linear relationship between landslides and its triggering factors. Rainfall events, for example, need to exceed a certain threshold to initialise landslides. Moreover, significant correlations might be obscured by the low temporal resolution of the air photographs (and thus low resolutions of landslide increase).

\subsubsection{Land use management practice}

Land use management practice is a further dynamic factor. The change of management practice is apparent from the pasture maps of 1955 and 2006 (Fig. 7). The private land is situated at the valley floor and adjacent slopes. Different forms of pastures (goat, cattle, and sheep) can be found on the slopes. Comparing the two maps, the following developments are noticeable between 1959 and 2006:

a) Goat pastures disappeared in 2006 .

b) The traditional land use type called "Freiberg" almost disappeared. "Freiberg" areas are pastures, which are used in spring because of the vicinity to the farms and the more advanced vegetation state at this altitudinal level. The 14th June is the appointed date to bring the cattle to the higher pastures. For the rest of the summer the Freiberg is kept as a reservoir in case of an early onset of the winter and is left to regenerate during the main growing season (note that the "Freiberg" were situated in the geological sensitive area of the Mesozoic layer).

c) Remote and less productive areas were abandoned.

d) Alpine cattle alps, which are high mountain pastures exclusively used during summer, disappeared completely to give way for sheep pastures.

Interviews with two farmers were conducted to complete the information of the pasture maps. The farmers were asked which kind of land use changes happened and where changes in land use intensity occurred since 1955 . The observations and experiences of the farmers can be summarised in two general developments: (i) an intensification of the areas close to the valley (point 1 to 6 , see below) and (ii) an extensification of remote areas (point 7 to 9, see below). The developments are ascribed to the following agricultural changes that agree with developments described for other alpine regions (Tasser and Tappeiner, 2002; Troxler et al., 2004; Mottet et al., 2006; Tappeiner et al., 2006; Baur et al., 2007):

(1) Permanent herding was replaced by uncontrolled grazing within fenced pastures, where animals concentrate on single locations, e.g. at the watering place. (2) Steep areas that are difficult to access and that have formerly been mown by hand (wild haying) were converted to pastures. (3) The number of external pasture animals delivered from the low lands outside of the valley increased. The animals are delivered to an appointed date independent of the actual vegetation status in the area. (4) Compulsory labour that was spent for the maintenance of the pastures was abolished. (5) The land use type "Freiberg" was largely abolished. The areas are now pastured throughout the entire season. (6) The private land is nowadays more frequently mown with machines and intensely fertilized with organic manure. (7) The stocking on the alps with dairy cows was reduced because of increased mother cow husbandry. The latter is mainly proceeded at the valley floor due to difficulties in herding and a more frequent need for veterinarian assistance. (8) The shrub cover increased due to cessation of wild haying, firewood collection, and reduced stocking of the alps with cattle and goats. Especially goat grazing hampers the invasion of shrubs (Luginbuhl et al., 2000). (9) The number of farmers declined (e.g., in the Urseren Valley from 77 in 1970 to 31 in 2006). Simultaneously, there are less full-time farmers. 


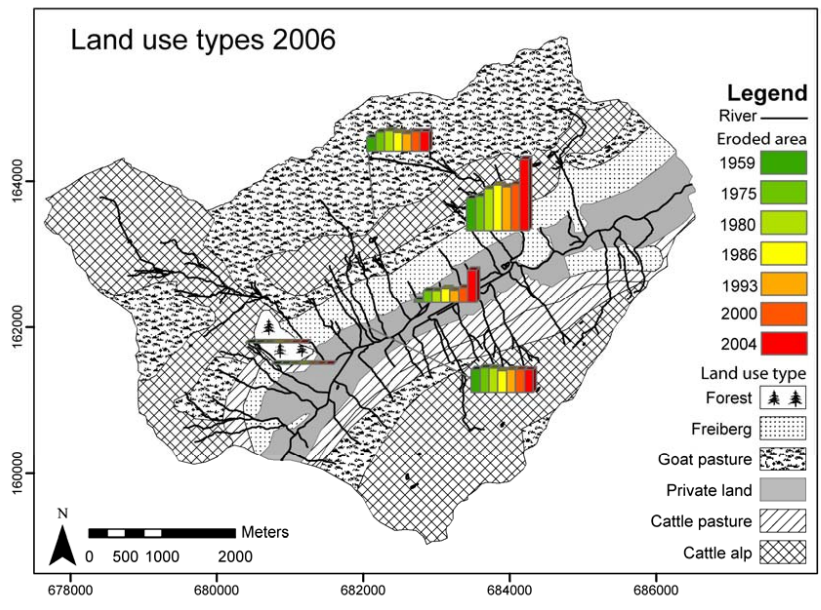

Fig. 8. Progression of landslide affected area on different traditional land use types of 1955 .

Most of the changes took place in the beginning of the 1970s as local agriculture became mechanised and traditional farming practices were abandoned. To show the effect of the above described developments on soil stability, the landslide areas for single years are displayed for each traditional land use type of 1955 (Fig. 8). The remote and extensively used pastures were already slightly affected by landslides in 1959 , but no increase in landslides could be observed over time. Today these areas are almost exclusively used as sheep pastures. The latter might indicate that sheep are not the main cause of the increase of landslide frequency. However, the data basis does not allow deducing recommendations for a specific pasture animal because the sheep and cattle pastures differ too much in catchment characteristics. Additionally, cattle pastures are temporarily used as sheep pastures; especially in spring when soils are most sensitive. The intensified areas closer to the valley floor (the former "Freiberg" and private land) have clearly destabilised. The "Freiberg" zone was already the most affected zone in 1959 due to its vulnerable geology, whereas the private land at that time was almost undisturbed.

\subsubsection{Land-cover: shrub encroachment}

Parallel and partly due to the above described changes in grassland management we determined an alteration of landcover, which manifests in an encroachment of shrubs. Landcover was not an independent parameter. Nor did it significantly improve the explained variance of the spatial landslide distribution in the multiple logistic regression model. Nonetheless, to evaluate the effect of land-cover change on the landslide trend, landslide densities are presented for the unchanged land-cover types and the areas that changed since 1959 separately (Table 1).

The shrub-cover was the only land-cover category, which showed considerable change over time. The area covered by shrubs increased since 1959 by $30.0 \%$. The landslide density
Table 1. Landslide densities for unchanged land-cover types and areas, that were invaded by shrubs since 1959 (new shrub).

\begin{tabular}{ll}
\hline land-cover & landslide density $(\%)$ \\
\hline forest & 0.0 \\
debris & 7.5 \\
new shrub & 2.9 \\
shrub & 33.2 \\
grassland/dwarf-shrub & 56.4 \\
\hline
\end{tabular}

is $33.2 \%$ for the community of old shrubs, but only $2.9 \%$ for the new shrubs. The older shrub cover mainly occurs in typical places for Alnus viridis i.e. on sites with wet conditions, like tributary channels on the north-facing slope. Especially these wet and steep areas close to channels are susceptible to landslides. The new shrub cover, however, occurred in untypical places for Alnus viridis on the plains between the channels and on the south exposed slope. These recently invaded areas show low susceptibility to landslides. The highest landslide densities could be observed for vegetation communities (defined in chapter 2) of dwarf-shrub and grassland $(56.4 \%)$. Debris is with $7.5 \%$ relatively less susceptible to landslide activity, as the inhomogeneous mixture of materials and grain sizes stabilises the soils. The small forested area $(0.7 \%$ of the catchment) is not affected by landslides.

Extensive investigations have shown that vegetation cover, especially woody shrub type (such as Alnus viridis, Sorbus aucuparia, Acer pseudoplatanus, Pinaceae and Fagaceae) help to improve stability of the slopes (Schauer, 1975; Newesely et al., 2000). Generally, vegetation has three effects on slope stability: (i) the mechanical anchoring of the soil, (ii) regulation of the soil water budget (iii), and the mechanical resistance to snow or snow gliding. Snow gliding can cause fissures in the soil cover that are potential tear-off lines for landslides (Schauer, 1975; Newesely et al., 2000). Alnus viridis constitutes the major species within the shrub category and is known to facilitate snow gliding (Newesely et al., 2000). Nevertheless, this category was less affected by landslides than the grassland/dwarf-shrub category that consists mainly of pastures with high proportions of Rhododendron ferrugineum that were found to stabilise the snow cover. We thus conclude that the effect of the land-cover on the landslide probability via the process of snow gliding is most likely of minor importance at our site. The cause for the low landslide susceptibility of the new shrub category can probably be explained by the two other functions of vegetation. Alnus viridis is often used in bioengineering to mechanically stabilise slopes with its roots (Graf et al., 2003). In addition, the high evapotranspiration rates of Alnus species (Herbst et al., 1999) and the affinity to wet conditions is effective in regulating the soil water budget (Wiedmer and Senn-Irlet, 2006). However, we can not directly deduce a stabilising 
effect of Alnus viridis from our data and can not exclude that Alnus viridis invaded preferably the more stable regions for some unknown reasons.

To summarise, we can see a clear impact of the changed management practice in the Urseren Valley: The accessible, more intensely used areas destabilised whereas areas of extensification to the point of abandonment did not destabilise. The effect of abandonment and the subsequent succession states on slope stability has been discussed in literature in detail (Schauer, 1975; Karl, 1977; Bunza, 1984; Newesely et al., 2000; Tasser et al., 2003). The fact that a reduction of the agricultural use enhances landslides risk is ascribed to increased snow-gliding on these areas (Schauer, 1975), to the higher vulnerability of the succession states and less maintenance (Tasser et al., 2003). For the Urseren Valley, this effect could not be observed. One possible explanation is that an increase of landslides on abandoned land mainly occurs on areas with a slope above $58^{\circ}$ inclination (Karl et al., 1985; Mössmer, 1985; Bätzing, 1996), where we could not observe landslides in the Urseren Valley. Furthermore, areas recently (since 1959) colonised by Alnus viridis show low landslide density. Mainly species such as Alnus viridis, Sorbus aucuparia and Rhododendron ferrugineum invade in the Urseren Valley, which are believed to increase soil stability. This is crucial information because the invasion of shrubs, is observed for the whole sub-alpine belt of the Swiss Alps. An increase of almost $11.8 \%$ was assessed for Alnus viridis between 1983/85 and 1993/1995 (Brassel and Brändli, 1999).

We found that the consequence of abandonment of the remote pastures which is the accompanying intensification through concentration of animals on smaller areas in combination with increasing stocking numbers is a greater threat to soil stability than the abandonment itself. Although less pronounced than in the Urseren Valley, this is a general agricultural development in the Swiss Alps (Baur et al., 2007; Troxler et al., 2004). The area of summer pastures steadily decreases (from 612619 ha in 1954 to 465519 ha in 2005 BFS, 2005) due to abandonment and subsequent emergence of shrubs and reforestation but simultaneously the stocking numbers increase. For example the summered sheep increased from 200000 to 420000 in the last 40 years (Troxler et al., 2004) and the livestock unit from 401921 in 1954 to 416566 in 1992 (Baur et al., 2007).

The change in management practice is driven by the decrease of farm numbers and farmers, which resulted in less maintenance and the abandoning of time-consuming traditional farming practices and non-profitable farmland since the early 1960s. In general, this leads on the one hand to abandonment and on the other hand to an intensification of the most profitable and accessible areas in the Swiss Alps and other mountainous regions (Tasser and Tappeiner, 2002; Mottet et al., 2006 ). These two extreme states of land use intensity are believed to be most vulnerable to landslides (Tasser and Tappeiner, 2002) and will most likely increase in the future.

\section{Conclusions}

We found a natural susceptibility of the catchment to landslides that has been proved by multivariate analysis. Geology and slope were identified as plausible factors to explain the spatial variation of landslides. However, quasi-static environmental factors like geology, and morphology cannot explain the temporal trend in landslide activity. The increase of the landslide area of $92 \%$ within 45 years confirms our hypothesis that dynamic factors like climate and land use decisively influence the landslide pattern that we observe today. The analysis of the time-series of avalanches revealed that avalanches seem to be of minor importance in triggering landslides. The increase of extreme rainfall events and the increased stocking of the pastures are likely to have enhanced the landslide hazard. In order to quantify the proportion of climate change and to separate its impact form land use the application of a deterministic landslide model seems a promising future task (Collison et al., 2000; Schmidt and Dikau, 2004). In addition to stocking numbers, the change in management practices is decisive. Extensively used or abandoned areas with recently emerging shrub vegetation show low landslide densities in the Urseren Valley and were not responsible for the landslide trend.

Land use affected the spatial distribution of landslides and created new landslide risk areas. In this context, it was shown that not abandonment itself but the accompanying intensification of accessible regions poses a major threat to soil stability in the valley. Although we cannot infer quantitative relationships between landslide hazard and anthropogenic impacts, our data indicate an increase of landslide hazard that duplicated the affected area by landslides. The case study in the Urseren Valley clearly highlights the relevance of dynamic anthropogenic driven impacts on landslide hazard. Many of the described developments are representative for other alpine regions, however, it remains to be shown if the impact on landslides is as significant.

Even though estimated soil loss due to landslides might be low compared to arable areas $\left(0.6 \mathrm{tha}^{-1} \mathrm{yr}^{-1}\right.$ compared to $2-\mathrm{tha}^{-1} \mathrm{yr}^{-1}$ as a limit value in the Swiss soil protection guideline BAFU, 2001), the areal damage is critical. Thus, there is a strong need, that soil loss through landslides is considered in erosion risk models and for guidelines and limit values adapted to mountain ecosystems. 
Acknowledgements. This study was funded by the Swiss Federal Office for the Environment. The authors gratefully acknowledge the supply of data by MeteoSwiss, Korporation Urseren, Swiss Federal Institute for Snow and Avalanche Research (SLF), and Swissphoto. Furthermore, we would like to thank T. Labhart, M. Mueller and the members of the Transdisciplinary Project Urseren (TPU) for valuable support and discussions.

Edited by: K.-T. Chang

Reviewed by: L. Claessens and three other anonymous referees

\section{References}

Ahnert, F.: Einführung in die Geomorphologie, third edition ed., UTB, Stuttgart, 440 pp., 2003.

Alewell, C., Meusburger, K., Brodbeck, M., and Bänninger, D.: Methods to describe and predict soil erosion in mountain regions, Landscape and Urban Planning, in press, 2008.

Andre, M. F.: Depopulation, land-use change and landscape transformation in the French Massif Central, Ambio, 27, 351-353, 1998.

Ayalew, L. and Yamagishi, H.: The application of GIS-based logistic regression for landslide susceptibility mapping in the KakudaYahiko Mountains, Central Japan, Geomorphology, 65, 15, 2005.

Ayalew, L., Yamagishi, H., Marui, H., and Kanno, T.: Landslides in Sado Island of Japan: Part II. GIS-based susceptibility mapping with comparisons of results from two methods and verifications, Eng. Geol., 81, 432-445, 2005.

BAFU: Article 18 of the Ordinance of 7 December 1998. Relating to Agricultural Terminology (SR 910.91), Swiss Federal Office for the Environment (German: BAFU), 2001.

Bätzing, W.: Landwirtschaft im Alpenraum - Ansätze für eine Synthesedarstellung, in: Europäische Akademie Bozen (Hrsg.), Landwirtschaft im Alpenraum - unverzichtbar, aber zukunftslos, Blackwell Wissenschaftsverlag, Berlin, 229-242, 1996.

Baur, P., Müller, P., and Herzog, F.: Alpweiden im Wandel, AGRAR Forschung, 14, 254-259, 2007.

Beniston, M.: Mountain weather and climate: A general overview and a focus on climatic change in the Alps, Hydrobiologica, 562, 3-16, 2006.

BFS: The changing face of landuse. Landuse statistics of Switzerland, Bundesamt für Statistik, Bern, 2001.

BFS: Arealstatistik Schweiz: Zahlen - Fakten - Analysen, Bundesamt für Statistik, Neuchâtel, 99, 2005.

Brassel, P. and Brändli, U.: Schweizerisches Forstinventar, Ergebnisse der Zweitaufnahme 1993-1995, Birmensdorf, Eidgenössische Forschungsanstalt für Wald, Schnee und Landschaft, Bundesamt für Umwelt, Wald und Landschaft, Bern, 1999.

Bunza, G.: Oberflächenabfluss und Bodenabtrag in alpinen Grassökosystemen, Ver. Ges. Ökol., 12, 101-109, 1984.

Carrara, A., Cardinali, M., Detti, R., Guzzetti, F., Pasqui, V., and Reichenbach, P.: GIS techniques and statistical-models in evaluating landslide hazard, Earth Sur. Proc. Land, 16, 427-445, 1991.

Carson, M. A.: The mechanics of erosion, Pion Ltd., London, 174 pp., 1971.

Cernusca, A., Bahn, M., Chemini, C., Graber, W., Siegwolf, R., Tappeiner, U., and Tenhunen, J.: ECOMONT: a combined approach of field measurements and process-based modelling for assessing effects of land-use changes in mountain landscapes, Ecological modelling, 113, 167-178, 1998.

Claessens, L., Lowe, D. J., Hayward, B. W., Schaap, B. F., Schoorl, J. M., and Veldkamp, A.: Reconstructing high-magnitude/lowfrequency landslide events based on soil redistribution modelling and a Late-Holocene sediment record from New Zealand, Geomorphology, 74, 29-49, 2006.

Claessens, L., Schoorl, J. M., and Veldkamp, A.: Modelling the location of shallow landslides and their effects on landscape dynamics in large watersheds: An application for Northern New Zealand, Geomorphology, 87, 16-27, 2007.

Clerici, A., Perego, S., Tellini, C., and Vescovi, P.: A GISbased automated procedure for landslide susceptibility mapping by the Conditional Analysis method: the Baganza valley case study (Italian Northern Apennines), Environ. Geol., 50, 941961, 2006.

Collison, A., Wade, S., Griffiths, J., and Dehn, M.: Modelling the impact of predicted climate change on landslide frequency and magnitude in SE England, Eng. Geol., 55, 205-218, 2000.

Dai, F. C. and Lee, C. F.: Landslide characteristics and slope instability modeling using GIS, Lantau Island, Hong Kong, 42, 213, 2002.

Descroix, L. and Gautier, E.: Water erosion in the southern French alps: climatic and human mechanisms, CATENA, 50, 53-85, 2002.

Dommermuth, C.: Beschleunigte Bodenabtragungsvorgänge in der Kulturlandschaft des Nationalparks Berchtesgaden. Ursachen und Auswirkungen aufgezeigt am Beispiel des Jennergebiets, Forstwissenschaftliches Centralblatt, 114, 285-292, 1995.

Douglas, T., Critchley, D., and Park, G.: The deintensification of terraced agricultural land near Trevelez, Sierra Nevada, Spain, Global Ecol. Biogeogr. Lett., 4, 258-270, 1996.

Frei, C., Calanca, P., Schär, C., Wanner, H., Schaedler, B., Haeberli, W., Appenzeller, C., Neu, U., Thalmann, E., Ritz, C., and Hohmann, R.: Grundlagen.Klimaänderungen und die Schweiz 2050 - Erwartete Auswirkungen auf Umwelt, Gesellschaft und Wirtschaft., OcCC Report, OcCC Report, 2007.

Glade, T.: Landslide occurrence as a response to land use change: a review of evidence from New Zealand, CATENA, 51, 297-314, 2003.

Graf, C., Boell, A., and Graf, F.: Pflanzen im Einsatz gegen Erosion und oberflächennahe Rutschungen, Eidgenöss. Forsch.anst. WSL, Birmensdorf, 2003.

Gray, D. H. and Leiser, H. T.: Biotechnical slope protection and erosion control, Van Nostrand Reinlold, New York, 288 pp., 1982.

Greenway, D. R.: Vegetation and slope stability, Anderson, M. G.and Richards, K. S., Slope Stability., Wiley, Chichester, New York, 187-230, 1987.

Guzzetti, F., Carrara, A., Cardinali, M., and Reichenbach, P.: Landslide hazard evaluation: a review of current techniques and their application in a multi-scale study, Central Italy, Geomorphology, 31, 181, 1999.

Helsel, D. R., Mueller, D. K., and Slack, J. R.: Computer Program for the Kendall Family of Trend Tests, Scientific Investigations Report 2005-5275, 4, 2006.

Herbst, M., Eschenbach, C., and Kappen, L.: Water use in neighbouring stands of beech (Fagus Sylvatica L.) and blach alder (Alnus glutinosa (L.) Gaertn.), Ann. For. Sci., 56, 107-120, 1999.

IPCC: Climate Change 2007: The physical science basis. Summary 
for policymakers., 661, 10th session of working group I of the IPCC, Paris, 2007.

Kägi, H. U.: Die traditionelle Kulturlandschaft im Urserental: Beitrag zur alpinen Kulturgeographie, $\mathrm{PhD}$ thesis at University of Zurich, Switzerland, 212, 1973.

Karl, J.: Oberflächenabfluss und Bodenabtrag auf brachliegenden extensiv genutzten Flächen, DVWK (Deutscher Verband für Wasserwirtschaft und Kulturbau), 34, 1977.

Karl, J., Porzelt, M., and Bunza, G.: Oberflächenabfluss und Bodenabtrag bei künstlichen Starkniederschlägen, DVWK (Deutscher Verband für Wasserwirtschaft und Kulturbau), 71, 37-102, 1985.

Komac, M.: A landslide susceptibility model using the Analytical Hierarchy Process method and multivariate statistics in perialpine Slovenia, Geomorphology, 74, 17, 2006.

Krohmer, J. and Deil, U.: Dynamic and conservative landscapes? Present vegetation cover and land-use changes in the Serra de Monchique (Portugal), Phytocoenologia, 33, 767-799, 2003.

Küttel, M.: Zur Vegetationsgeschichte des Gotthardgebietes, Mittelungen der Naturforschenden Gesellschaft Luzern, 31, 100111, 1990a.

Küttel, M.: Der subalpine Schutzwald im Urserental - ein inelastisches Ökosystem, Bot. Helv., 100/2, 1990b.

Labhart, T. P.: Planbeilage: Geologisch-tektonische Übersichtskarte Aarmassiv, Gotthardmassiv und Tavetscher Zwischenmassiv, Balkema A. A., Rotterdam, 1999.

Luginbuhl, J.-M., Green, J. T., Poore, M. H., and Conrad, A. P.: Use of goats to manage vegetation in cattle pastures in the Appalachian region of North Carolina, Sheep and Goat Res. J., 16, 124-135, 2000.

Mössmer, E. M.: Einflussfaktoren für die Blaikenerosion auf beweideten und aufgelassenen Almflächen im kalkalpinen Bereich der Landkreise Miesbach und Rosenheim, Forstliche Forschungsberichte München, 1985.

Mottet, A., Ladet, S., Coque, N., and Gibon, A.: Agricultural landuse change and its drivers in mountain landscapes: A case study in the Pyrenees, Agriculture, Ecosystems and Environment, 114, 296-310, 2006.

Newesely, C., Tasser, E., Spadinger, P., and Cernusca, A.: Effects of land-use changes on snow gliding processes in alpine ecosystems, Basic Appl. Ecol., 1, 61-67, 2000.

Ohlmacher, G. C. and Davis, J. C.: Using multiple logistic regression and GIS technology to predict landslide hazard in northeast Kansas, USA, Eng. Geol., 69, 331, 2003.

Petley, D., Hearn, G., Hart, A., Rosser, N., Dunning, S., Oven, K., and Mitchell, W.: Trends in landslide occurrence in Nepal, Nat. Hazards, 43, 23-44, 2007.

Piégay, H., Walling, D. E., Landon, N., He, Q. P., Liébault, F., and Petiot, R.: Contemporary changes in sediment yield in an alpine mountain basin due to afforestation (The upper Drome in France), CATENA, 55, 183-212, 2004.

Rickli, C., Zimmerli, P., and Böll, A.: Effects of vegetation on shallow landslides: an analysis of the events of August 1997 in Sachseln, Switzerland, International Conference on Landslides, Causes, Impacts and Countermeasures, Essen, 575-584, 2001.
Ritzmann-Blickenstorfer, H.: Historische Statistik der Schweiz, Chronos Verlag, Zürich, 1996.

Santacana, N., Baeza, B., Corominas, J., De Paz, A., and Marturia, J.: A GIS-based multivariate statistical analysis for shallow landslide susceptibility mapping in La Pobla de Lillet area (Eastern Pyrenees, Spain), Nat. Hazards Earth Syst. Sci., 30, 281-295, 2003, http://www.nat-hazards-earth-syst-sci.net/30/281/2003/.

Schmidt, J., and Dikau, R.: Modeling historical climate variability and slope stability, Geomorphology, 60, 433-447, 2004.

Shrestha, D. P., Zinck, J. A., and Van Ranst, E.: Modelling land degradation in the Nepalese Himalaya, CATENA, 57, 135, 2004.

Sparling, G., Ross, D., Trustrum, N., Arnold, G., West, A., Speir, T., and Schipper, L.: Recovery of topsoil characteristics after landslip erosion in dry hill country of New Zealand, and a test of the space for time hypothesis, Soil Biol. Biochem., 35, 15751586, 2003.

Suezen, M. L. and Doyuran, V.: Data driven bivariate landslide susceptibility assessment using geographical information systems: a method and application to Asarsuyu catchment, Turkey, Eng. Geol., 71, 303-321, 2004.

Swisstopo: Reproduziert mit Bewilligung von swisstopo, BA071108, Zurich, 2006.

Tappeiner, U., Tasser, E., Leitinger, G., and Tappeiner, G.: Landnutzung in den Alpen: historische Entwicklung und zukünftige Szenarien, Die Alpen im Jahr 2020, alpine space-man and environment, 1, 23-39, 2006.

Tasser, E. and Tappeiner, U.: Impact of land use changes on mountain vegetation, Appl. Veg. Sci., 5, 173-184, 2002.

Tasser, E., Mader, M., and Tappeiner, U.: Effects of land use in alpine grasslands on the probability of landslides, Basic Appl. Ecol., 4, 271-280, 2003.

Troxler, J., Chatelain, C., and Schwery, M.: Technical and economical evaluation of grazing systems for high altitude sheep pastures in Switzerland, Grassland Science in Europe, 9, 590-592, 2004.

Van Westen, C. J. and Lulie Getahun, F.: Analyzing the evolution of the Tessina landslide using aerial photographs and digital elevation models, Geomorphology, 54, 77, 2003.

Vanacker, V., Vanderschaeghe, M., Govers, G., Willems, E., Poesen, J., Deckers, J., and De Bievre, B.: Linking hydrological, infinite slope stability and land-use change models through GIS for assessing the impact of deforestation on slope stability in high Andean watersheds, Geomorphology, 52, 299-315, 2003.

Wiedmer, E. and Senn-Irlet, B.: Biomass and primary productivity of an Alnus viridis stand - a case study from the Schächental valley, Switzerland, Bot. Helv., 116, 55-64, 2006.

WRB: IUSS Working Group World reference base for soil resources, Rom, 128 pp., 2006.

Wyss, R.: Die Urseren-Zone - Lithostatigraphie und Tektonik, Eclogae Geol. Helv., 79, 731-767, 1986.

Zhou, C. H., Lee, C. F., Li, J., and Xu, Z. W.: On the spatial relationship between landslides and causative factors on Lantau Island, Hong Kong, Geomorphology, 43, 197, 2002. 